\title{
Genotypic Characterization of Sulfur-0 xidative Desulfurizing Bacterial Strains Isolated from Mexican Refineries
}

\author{
I. Bustos-Jaimes ${ }^{1}$, G. Amador ${ }^{1}$, G. Castorena ${ }^{1}$ and S. Le Borgne ${ }^{1 *}$ \\ 1 Instituto Mexicano del Petróleo, Eje Central Lázaro Cárdenas 152, 07730 M éxico D.F. - M exico \\ e-mail: ibustos@imp.mx - guadalupeamador@hotmail.com - gcastore@imp.mx - slborgne@imp.mx \\ * Corresponding author
}

\begin{abstract}
Résumé - Caractérisation génotypique de souches bactériennes isolées de raffineries mexicaines, capables de désulfuration par oxydation du soufre - Nous avons effectué une caractérisation génotypique de nouvelles bactéries désulfurant le dibenzothiophène (DBT) par attaque spécifique de l'atome de soufre, isolées à partir de sols contaminés par des hydrocarbures et provenant de raffineries mexicaines. Nous les avons comparées à deux souches de référence (Rhodococcus erythropolis IGTS8 et $R$. erythropolis X309). Ces souches de référence ont déjà été très largement étudiées et sont protégées par des brevets, de même que les procédés de désulfuration qui en dérivent. L'objectif de cette étude était d'utiliser des techniques de biologie moléculaire pour caractériser ces souches nouvellement isolées et déterminer si elles étaient différentes des souches brevetées. Les méthodes de caractérisation employées ont été le séquençage partiel du gène de l'ADNr (ribosomal) 16S, l'amplification par PCR des gènes de la désulfuration, l'analyse de fragments de restriction et du polymorphisme après amplification aléatoire de fragments d'ADN (RAPD pour Random Amplified Polymorphic DNA). L'analyse des séquences des gènes de l' $\mathrm{ADNr} 16 \mathrm{~S}$ a montré que ces souches n'appartenaient pas à l'espèce $R$. erythropolis, même si elles contenaient les mêmes gènes $d s z A B C$ de la désulfuration que $R$. erythropolis IGTS8. Les profils de RAPD étaient également différents de ceux des souches de référence, confirmant que ces souches étaient différentes des souches déjà brevetées $R$. erythropolis IGTS8 et X309.
\end{abstract}

\begin{abstract}
Genotypic Characterization of Sulfur-Oxidative Desulfurizing Bacterial Strains Isolated from Mexican Refineries - We performed a genotypic characterization of new sulfur selective dibenzothiophene (DBT) desulfurizing strains which have been isolated from hydrocarbon contaminated soils originating from Mexican refineries. We compared them to two reference strains (strains Rhodococcus erythropolis IGTS8 and R. erythropolis X309). These reference strains have been extensively studied and are protected by patents as well as all biodesulfurization (BDS) processes derived from them. The aim of the present study was to use molecular tools to characterize these new isolates and determine whether they were different from the other patented strains. The characterization methods included $16 S$ rDNA gene partial sequencing, PCR amplification of fragments associated to the desulfurization phenotype, restriction analysis and randomly amplified polymorphic DNA (RAPD). Partial 16S rDNA gene sequence analysis showed that the isolated strains were different from R. erythropolis IGTS8 although they contained the same desulfurizing dszABC genes. The RAPD
\end{abstract}


patterns were also different from those of the two reference strains used in this study confirming that the isolated bacteria were different from the already patented desulfurizing strains $\mathrm{R}$. erythropolis IGTS8 and X309.

\section{IN TRO DUCTION}

The sulfur-containing compounds present in petroleum are transformed into atmospheric sulfur oxides by combustion of fuels, causing serious environmental problems such as acid rain. To reduce these emissions, the total sulfur content in fuels is reduced during refining of middle-distillate fractions such as diesel oil [1]. However, some sulfurcontaining compounds are recalcitrant to the thermochemical hydrodesulfurization (HDS) process presently used in refineries for the removal of sulfur [2]. These compounds mainly consist of DBT and its substituted derivatives and may represent $70 \%$ of the sulfur in some crude oils; they are particularly concentrated in the fractions used to produce diesel oil [3].

Since HDS may require hard conditions for the deep desulfurization (from 500 to $50 \mathrm{ppm}$ sulfur) of fractions containing DBTs, microbiological refining may be an attractive complement to the conventional HDS process. The BDS process operates under mild conditions of temperature and pressure. For these reasons, BDS has attracted the attention of some petroleum-refining industries in the last decade.

Bacteria able to mineralize DBT into $\mathrm{CO}_{2}$ and $\mathrm{H}_{2} \mathrm{O}$ or to accumulate 3-hydroxy-2-formylbenzothiophene have been described. Such bacteria are not good candidates for a commercial BDS process since they reduce the fuel energetic value [4]. On the other hand, some bacterial species have been isolated which can metabolize DBT via a sulfur-specific elimination pathway, the 4S pathway (Fig. 1) [5-13]. Among these strains, the patented Rhodococcus erythropolis IGTS8 strain has been the most extensively studied one and it was the basis of the commercial process proposed by the North American Energy Biosystems Corporation [5].

The genes $d s z A B C$, coding for the enzymes of the $4 \mathrm{~S}$ metabolic pathway in $R$. erythropolis IGTS8, have been found in large plasmids [14]. Loss of the DBT-desulfurizing phenotype has been clearly related to the loss of these plasmids [15]. The $d s z D$ gene, coding for the DszD flavin reductase involved in the monooxygenase reactions, is not located on a plasmid [16]. The genes $d s z A B C$ are grouped in a $3.7 \mathrm{~kb}$ operon called the $d s z$ operon (Fig. 2). This system is repressed in the presence of easily metabolizable sources of sulfur such as sulfate or sulfur containing aminoacids [17].

Many of the strains reported to have the $4 \mathrm{~S}$ metabolic pathway are patent-protected. In the present work, we used molecular biology techniques to determine the genotypic differences between the strains we isolated and previously reported strains, R. erythropolis ITGS8 and X309, which belong to Energy Biosystems Corporation and Exxon, respectively.
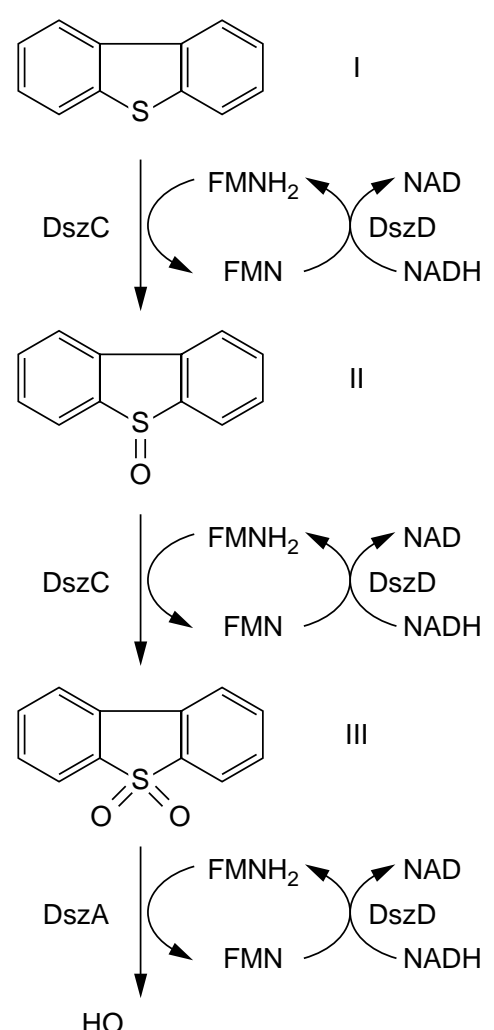<smiles>O=S(O)c1ccccc1-c1ccccc1O</smiles>

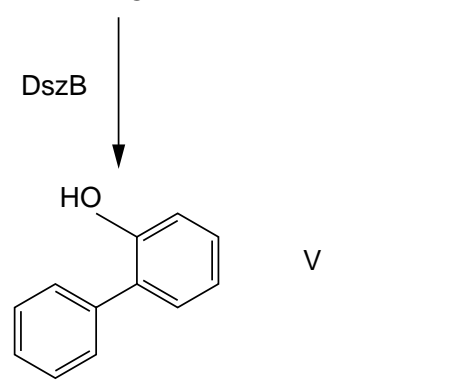

Figure 1

$4 \mathrm{~S}$ metabolic pathway for DBT desulfurization. DszC, DBT monooxygenase; DszA, DBT sulfone monooxygenase; DszB, HPBS desulfinase; DszD, flavin reductase. I, DBT; II, DBT sulfoxide; III, DBT sulfone; IV, hydroxyphenylbenzenesulfinate; V, 2-hydroxybiphenyl. 


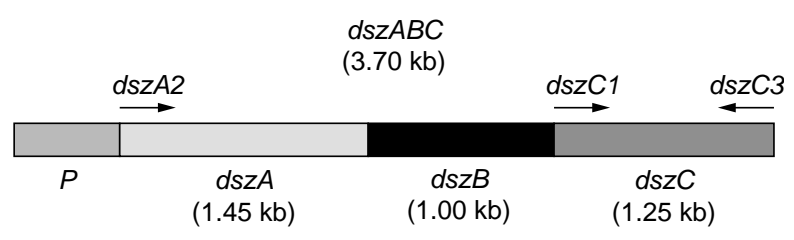

Figure 2

Organization of the $d s z A B C$ operon of $R$. erythropolis ITGS8.

\section{MATERIALS AND METHODS}

\subsection{Isolation and Identification of Strains}

The DBT-desulfurizing bacteria used in this study were isolated from hydrocarbon-contaminated soils from different Mexican oil refineries. The following strains were used for comparison: $R$. erythropolis IGTS8 (ATCC 53968) and $R$. erythropolis X309 (ATCC 55309). A minimal salt medium (MSM) was used for the isolation and cultivation of DBTdesulfurizing strains [18]. DBT and 4,6-dimethylDBT (4,6DMDBT) were dissolved in hexane $(50 \mathrm{mM})$ and added to the sterilized MSM. For solid media preparation, MSM agar plates were coated with $1 \mathrm{ml}$ of DBT solution for a final $2 \mathrm{mM}$ concentration. Cultures were incubated on a rotary shaker at $180 \mathrm{rpm}$ at $30^{\circ} \mathrm{C}$. Initial enrichment cultures were prepared by adding soil samples to MSM supplemented with $14 \mathrm{mM}$ dimethylsulfoxide. Dimethylsulfoxide was used in the initial steps of the enrichment procedure since it is more easily metabolized than DBT and can also induce the DBT sulfur-oxidative desulfurization genes. Colonies of DBTdegrading bacteria were then obtained by plating the enrichment cultures on DBT-coated MSM agar plates. Preliminary characterization of bacterial strains was made by macroscopic observation, microscopy and gram staining. Both strands of the first 523 bases of the 16S rRNA gene were sequenced by Midi Labs (Newark, DEL, United States) after PCR using primers that anneal at the positions beginning at base pair 8, 5P-AGAGTTTGATCITGGCTCAG-3P, and 536, 5P-GTATTACCGCGGCTGCTGGCAC-3P, in the 16S rDNA gene of E. coli.

\subsection{RAPD Analysis and PCR Amplification of the $d s z O$ peron and the $d s z C$ Gene}

Genomic DNA was isolated from $15 \mathrm{ml}$ of a suspension of cells cultivated in MSM supplemented with $1.5 \mathrm{mM}$ DBT (and harvested during the stationary phase) by using a cetyl trimethylammonium bromide method [19]. Bacteria were incubated at $37^{\circ} \mathrm{C}$ for $1 \mathrm{~h}$ with $375 \mathrm{U}$ of mutanolysin before adding lysozyme to improve cell lysis [20]. RAPD-PCRs were performed using ready-to-go RAPD analysis beads and primers 1, 2 and 6 (Amersham Pharmacia Biotech, Piscataway, NJ, United States). The PCR primers for the amplification of the desulfurization genes were designed using DNA sequences from strain IGTS8 (GenBank accession number U08850). PCR primers for the $d s z C$ gene amplification were $d s z C l, 5 \mathrm{P}-$ CGCGAATTCATGACACTGTCACCTGAAAAGCAGC3P ( $d s z C$ start codon is underlined), and $d s z C 3$, 5PCCCAAGCTTCTCAGATCCTCAGGAGGTGAAGCCGGG-3P ( $d s z C$ stop codon is underlined). For the $d s z$ operon, primers $d s z A 2$, 5P-CGCGAATTCAGGACGCATACGCGATGACTCAACAAC-3P ( $d s z A$ start codon is underlined), and $d s z C 3$ were used. Amplification was performed with the Taq polymerase (Amersham Pharmacia Biotech) according to the manufacturer's recommendations. The PCR conditions were as follows:

- one cycle of $1 \mathrm{~min}$ at $95^{\circ} \mathrm{C}$;

- 30 cycles consisting of $1 \mathrm{~min}$ at $95^{\circ} \mathrm{C}, 1 \mathrm{~min}$ at $60^{\circ} \mathrm{C}$ and 1.5 (for $d s z C$ ) or $4 \mathrm{~min}$ (for $d s z$ ) at $72^{\circ} \mathrm{C}$;

- and a final cycle of $10 \mathrm{~min}$ at $72^{\circ} \mathrm{C}$.

\subsection{Analytical Methods}

DBT, 4,6-DMDBT and their metabolites were analyzed by high-performance liquid chromatography (HPLC) using a Hewlett-Packard (model HP1100) system, with a SRP-18 Waters column. Elution was performed with an 80/20 (v/v) acetonitrile/water mobile phase at $1 \mathrm{ml} \cdot \mathrm{min}^{-1}$ and detection was carried out with a UV detector at $225 \mathrm{~nm}$. For HPLC analysis, cultures were extracted with equal volumes of acetonitrile. DBT and 4, 6-DMDBT metabolites were also analyzed by gas chromatography-mass spectrometry (GCMS) using a Hewlett-Packard (model 6890) chromatograph coupled to a mass spectrometer (model 5973). The gas chromatograph was equipped with a HP capillary column HP-5\% phenyl methyl siloxane $(30 \mathrm{~m} \times 250 \mu \mathrm{m} \times 0.25 \mu \mathrm{m})$. The oven temperature was programmed from $100^{\circ} \mathrm{C}$ to $270^{\circ} \mathrm{C}$ with an increasing rate of $7^{\circ} \mathrm{C} \mathrm{min}^{-1}$. For GC-MS analysis, culture media were acidified to $\mathrm{pH} 2$ with $\mathrm{HCl}$ and extracted with toluene. Extracts were dried over anhydrous $\mathrm{Na}_{2} \mathrm{SO}_{4}$ and concentrated by evaporation. Total sulfur content was determined in culture supernatants by X-ray fluorescence with a Horiba sulfur analyzer (model SLFA-1100H).

\section{RESULTS AND DISCUSSION}

Four aerobic desulfurizing bacterial strains, able to grow using DBT as the sole source of sulfur were isolated. The culture of these bacteria in MSM supplemented with DBT or 4,6-DMDBT produced 2-hydroxybiphenyl and 2-hydroxy3,3 '-dimethyl biphenyl respectively, which are the products expected from the $4 \mathrm{~S}$ metabolic pathway (data not shown here). These strains were named S02, S06, S24 and A17. It should be pointed out that 4,6-DMDBT is one of the most difficult DBT derivative to be removed by HDS. 
The strains were identified by partial $16 \mathrm{~S}$ rDNA sequence analyses. The alignment of these 16S rDNA partial sequences indicated a very close relation of the isolated strains with the Rhodococcus genus (Table 1). 16S rDNA sequences of the four isolates were identical and a $99.8 \%$ identity was found with $R$. globerulus. The sole difference between these strains and $R$. globerulus was found at position 400 where there was a $\mathrm{T}$ instead of a $\mathrm{C}$. Complete sequencing of the $16 \mathrm{~S}$ rDNA genes of these strains should be performed in order to confirm these data.

TABLE 1

Identification of the isolated strains

by $16 \mathrm{~S}$ rDNA gene sequence analysis

\begin{tabular}{c|c|c}
\hline $\begin{array}{c}\text { Genetic } \\
\text { differences (\%) }\end{array}$ & $\begin{array}{c}\text { Size of the } \\
\text { DNA sequence (bp) }\end{array}$ & Microorganism \\
\hline 0 & 500 & S02, S06, S24 and A17 \\
0.2 & 500 & Rhodococcus globerulus \\
1.6 & 500 & Rhodococcus erythropolis \\
2.8 & 500 & Rhodococcus opacus \\
3 & 500 & Rhodococcus fascians \\
4 & 502 & Rhodococcus equi \\
\hline
\end{tabular}

It is also important to differentiate the strains among them and from the control strains. Many techniques have been described that allow differentiating bacterial strains according to their genotypic diversity. The method used was RAPD which allows the identification of small differences between similar genomes, i.e. at the genus, species or strain levels $[21,22]$. RAPD analysis uses a single short oligonucleotide primer of arbitrary sequence in a low stringency PCR reaction. This method does not require previous knowledge of any DNA sequences and it also has a high resolving power to detect genetic differences between bacteria. The RAPD patterns generated for the isolated strains as well as the controls are shown in Figure 3. The differences between the control strains IGTS8 and X309 are quite clear since easily distinguishable patterns were obtained (Fig. 3, lanes 2 and 7). Strains S02, S06, S24 and A17 displayed four distinct patterns, which are quite different from the controls (Fig. 3, lanes 3 to 6). The differences between strains $\mathrm{S} 02$ and S24 on the one hand and S06 and A17 on the other hand are not very conspicuous. However, slight differences appeared between S02 and S24: the $1.4 \mathrm{~kb}$ band has a different intensity in the two strains and a $0.6 \mathrm{~kb}$ band is present in S02 only (Fig. 3, lanes 3 and 5). In the case of S06 and A17, a faint $1.1 \mathrm{~kb}$ band is present in A17 and absent in S06 (Fig. 3, lanes 4 and 6). These results suggested that the four isolated strains were genetically different. However, this analysis did not allow to infer differences in the genes associated to DBT desulfurization.

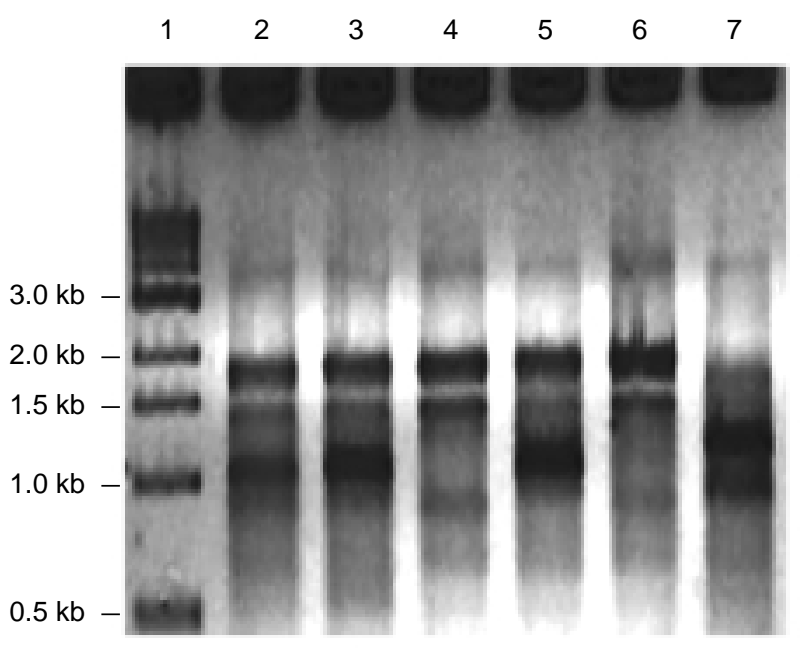

Figure 3

RAPD analysis of the DBT-desulfurizing strains.

Lanes: 1, molecular-weight marker; 2, IGTS8; 3, S02; 4, S06; 5, S24; 6, A17; 7, X309.

The presence of identical $d s z A B C$ genes in the $\mathrm{S} 02, \mathrm{~S} 06$, S24 and A17 strains was investigated using a PCR-based analysis. PCR amplification of the $d s z A B C$ operon (Fig. $4 a$ ) and the $d s z C$ gene (Fig. $4 b$ ) showed that:

- the $d s z$ genes of the isolated strains could be amplified using primers designed from the control strains;

- the amplicons had the expected size. In addition, the amplicons of the genes amplified from the strains $\mathrm{S} 02$, S06, S24, A17 and those of the controls had the same molecular weight and thus probably the same structural organization, $d s z A-d s z B-d s z C$.

Moreover, some restriction endonucleases were used to digest the $d s z A B C$ PCR products and the generated restriction patterns were identical for all strains (data not shown here). These data showed that identical $d s z A B C$ genes were present in the four strains isolated here and in the control strains IGTS8 and X309.

The importance of the genetic differences between Rhodococci not only arises from patent issues; it is also important to infer the different desulfurizing properties and morphological aspects of different desulfurizing strains. Even though many strains have identical $d s z A B C$ genes, they present clear phenotypic differences that could explain the differences of their behavior in terms of BDS activity and solvent tolerance for example. These differences may be critical for the success or the failure of a BDS process. The differences in desulfurizing behavior may be related to differences in cell surface hydrophobicity, mass transport through the cell walls and membranes as well as distinct carbon fluxes and metabolic regulations inside the cell. 

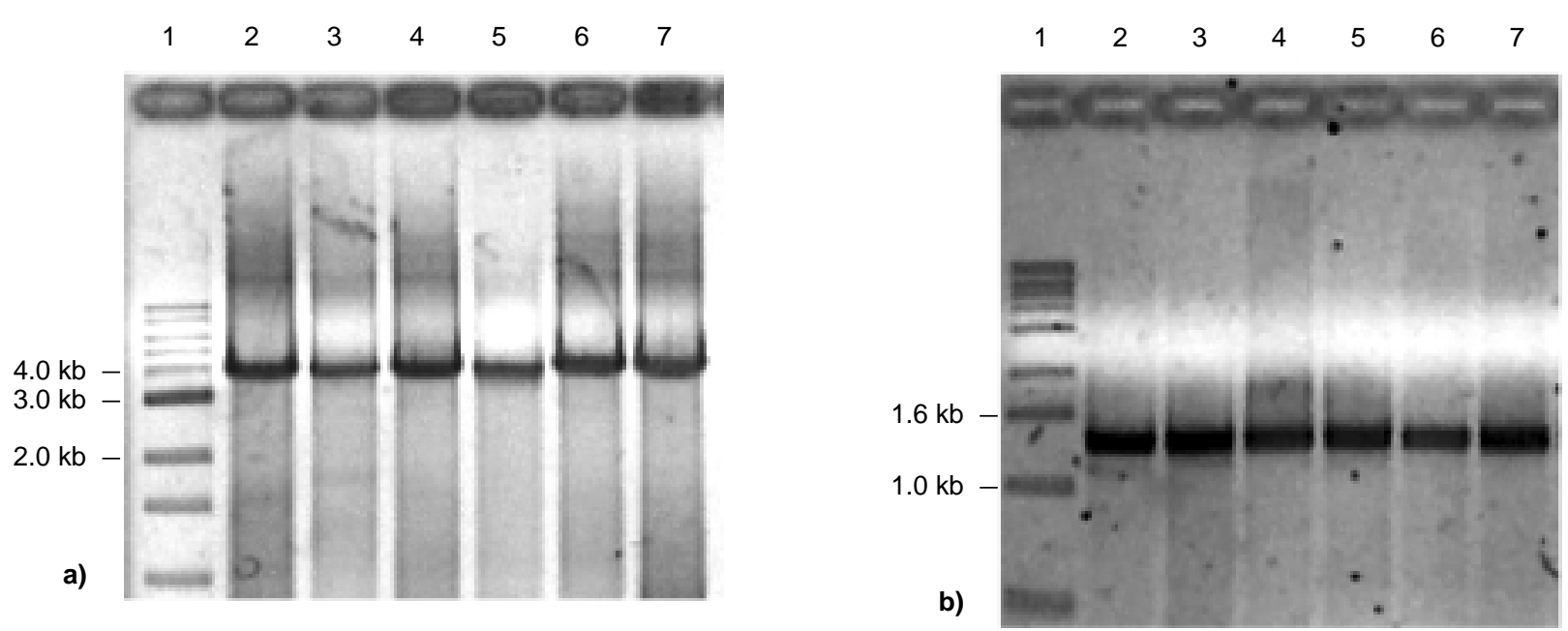

Figure 4

PCR amplification of the $d s z A B C$ operon (a) and the $d s z C$ gene (b).

Lanes: 1, molecular weight marker; 2, IGTS8; 3, S02; 4, S06; 5, S24; 6, A17; 7, X309.

\section{CON CLUSION}

Four sulfur-oxidative bacterial strains were isolated from Mexican refineries. These strains were identified as members of the genus Rhodococcus and showed genetic differences with the previously reported $R$. erythropolis IGTS8 and X309 desulfurizing strains. Nevertheless, the $d s z A B C$ operon of the bacteria isolated in this work seems to have the same structural organization as that of the control strains. Further studies on the genetic differences between these strains may explain the differences observed in their desulfurizing properties.

\section{REFEREN CES}

1 Monticello, D.J. (1998) Riding the Fossil Fuel BioDesulfurization Wave. Chemtech, 28, 38-45.

2 Kabe, T., Akamatsu, K., Ishihara, A., Otsuki, S., Godo, M., Zhang, Q. and Qian, W. (1997) Deep Hydrodesulfurization of Light Gas Oil. 1. Kinetics and Mechanisms of Dibenzothiophene Hydrodesulfurization. Ind. Eng. Chem. Res., 36, 5146-5152.

3 Monticello, D.J. and Finnerty, W.R. (1985) Microbial Desulfurization of Fossil Fuels. Annu. Rev. Microbiol., 39, 371-389.

4 Ohshiro, T. and Izumi, Y. (1999) Microbial Desulfurization of Organic Sulfur Compounds in Petroleum. Biosc. Biotechnol. Biochem., 63, 1, 1-9.

5 Kilbane, J.J. (1992) Mutant Microorganisms Useful for Cleavage of Organic C-S Bonds. US Patent 5104801.

6 Izumi, Y. Ohshiro, T., Ogino, H., Hine, Y. and Shimao, M. (1994) Selective Desulphurization of Dibenzothiophene by Rhodococcus erythropolis D-1. Appl. Environ. Microbiol., 60, 223-226.

7 Lee, M.K., Senius, J.D. and Grossman, M.J. (1995) SulfurSpecific Microbial Desulfurization of Sterically Hindered
Analogs of Dibenzothiophene. Appl. Environ. Microbiol., 61, 4362-4366.

8 Ohshiro, T., Hirata, T., Hashimoto, I. and Izumi, Y. (1996) Characterization of Dibenzothiophene Desulfurization Reaction by Whole Cells of Rhodococcus H-2 in the Presence of Hydrocarbon. J. Ferment. Bioeng., 82, 610-612.

9 Konishi, J., Ishii, Y., Onaka, T., Okumura, K. and Suzuki, M. (1997) Thermophilic Carbon-Sulfur-Bond-Targeted Biodesulfurization. Appl. Environ. Microbiol., 63, 3164-3169.

10 Rhee, S.K., Chang, J.H., Chang, Y.K. and Chang, H.N. (1998) Desulphurization of Dibenzothiophene and Diesel Oils by a Newly Isolated Gordona Strain, CYKS1. Appl. Environ. Microbiol., 64, 2327-2331.

11 Chang, J.H., Rhee, S.K., Chang, Y.K. and Chang, H.N. (1998) Desulfurization of Diesel Oils by a Newly Isolated Dibenzothiophene-Degrading Nocardia sp. Strain CYKS2. Biotechnol. Prog., 14, 851-855.

12 Darzins, A. and Mrachko, G.T. (2000) Sphingomonas Biodesulfurization Catalyst. US Patent No. 6133016.

13 Kirimura, K., Furuya, T., Nishii, Y., Ishii, Y., Kino, K. and Usami, S. (2001) Biodesulfurization of Dibenzothiophene and its Derivatives Through the Selective Cleavage of Carbon-Sulfur Bonds by a Moderately Thermophilic Bacterium Bacillus subtilis WU-S2B. J. Biosc. Bioeng., 91, 262-266.

14 Denis-Larose, C., Labbé, D., Bergeron, H., Jones, A.M., Greer, C.W., Al-Hawari, J., Grossman, M.J., Sankey, B.M. and Lau, P.C.K. (1997) Conservation of Plasmid-Encoded Dibenzothiophene Desulfurization Genes in Several Rhodococci. Appl. Environ. Microbiol., 63, 2915-2919.

15 Denome, S.A.E., Olson, E.S. and Young, K.D. (1993) Identification and Cloning of Genes Involved in Specific Desulfurization of Dibenzothiophene by Rhodococcus sp. Strain IGTS8. Appl. Environ. Microbiol., 59, 2837-2843.

16 Oldfield, C., Wood, N.T., Gilbert, S.C., Murray, F.D. and Faure, F.R. (1998) Desulphurization of Benzothiophene and Dibenzothiophene by Actinomycete Organisms Belonging to the Genus Rhodococcus, and Related Taxa. Antonie van Leuwenhoek, 74, 119-132. 
17 Li, M.Z., Squires, C.H., Monticello, D.J. and Childs, J.D. (1996) Genetic Analysis of the $d s z$. Promoter and Associated Regulatory Regions of Rhodococcus erythropolis IGTS8. J. Bacteriol., 178, 6409-6418.

18 Gilbert, S., Morton, J., Buchanan, S., Oldfield, C. and McRoberts, A. (1998) Isolation of a Unique Benzothiophene Desulphurizing Bacterium, Gordona sp. Strain 213E (NCIMB 40816), and Characterization of the Desulphurization Pathway. Microbiology, 144, 2545-2553.

19 Ausubel, F.M., Brent, R., Kingston, R. E., Moore, D.D., Seidman, J.G., Smith, J. A. and Struhl, K. (1995) Short Protocols in Molecular Biology, 3rd ed, John Wiley and Sons Inc., New York.
20 Assaf, N.A. and Dick, W.A. (1993) Spheroplast Formation and Plasmid Isolation from Rhodococcus sp. Biotechniques, 15, 1010-1015.

21 Wang, G., Whittam, T.S., Berg, C.M., Berg, D.E. (1993) RAPD (Arbitrary Primer) PCR is more Sensitive than Multilocus Enzyme Electrophoresis for Distinguishing Related Bacterial Strains. Nucleic Ac. Res., 21, 5030-5933.

22 Rodríguez, J.G., Mejía, G.A., Del Portillo, P., Patarroyo, M.E., Murillo, L.A. (1995) Species Specific Identification of Mycobacterium bovis by PCR. Microbiology, 147, 21312138.

Final manuscript received in April 2003 